\title{
Human interleukin-1 receptor antagonist is expressed in liver
}

\author{
Alexander Steinkasserer", Cornelia Estaller ${ }^{\mathrm{b}}$, Elisabeth H. Weiss ${ }^{\mathrm{b}}$ and Robert B. Sim ${ }^{\mathrm{a}}$ \\ "MRC Immunochemistry Unit, Deparment of Biochemistry, University of Oxford, South Parks Road, Oxford, OXI $3 Q U, U K$ and \\ "Institute of Immunology, University of Munich, Goethestr. 31, 8000 Mt:mich-2, Germany
}

Received 14 July 1992

Using PCR and Northern blot analysis, an IL-1 receptor antagonist specific transcript was amplified from HepG2-and liver mRNA. cDNA clones coding for IL-1 receptor antagonist were isolated from a liver eDNA library and sequence comparison revealed complete identity with the secreted, monocylic form of $1 \mathrm{~L}-1$ receptor anlagonist.

IL-1 receptor antagonist; Liver; cDNA transcript

\section{INTRODUCTION}

IL-1 receptor antagonist (IL-1 ra) is a protein which inhibits IL-1 (IL-1 $\alpha$ and IL-1 $\beta$ ) activity, by binding competitively to IL-1 receptors [1]. This naturally occurring inhibitor has been shown to reduce the severity of sepsis, colitis, arthritis and diabetes in animals and it therefore plays an important role in the control of IL- 1 mediated inflammatory and autoimmune diseases [2]. IL-1 ra is structurally related to IL-1 and shows $18 \%$ and $26 \%$ identity in amino acid sequence to IL- $\mid \alpha$ and II $-1 \beta$, respectively.

The cDNA sequence of IL-1 ra derived from monocytes has been previcusly determined [3] and using an intronic polymorphism [4] the localization of the gene on chromosome 2 has been established by linkage analysis [5], as well as by in situ hybridisation [6].

There are two types of IL-1 ra, one secreted, soluble form expressed in monocytes and neutrophils and an intracellular form expressed in epithelial cells. This intracellular IL-1 ra, which lacks a leader peptide, is derived from the same gene through the use of an alternative transcriptional start site and alternative splicing [7].

In this study we report the expression of the secreted form of the 1L-1 ra in liver.

\section{MATERIALS AND METHODS}

\section{1. cDNA syndhesis and PCR anulification}

Total RNA was isolated from the human cell lines HepG2, Chang, U937, Daudi, HL60, Molt4, Raji and T47D as well as from liver, temporal cortex and lung tissue using guanidinium thiocyanate and a $\mathrm{CsCl}$ gradient [8]. $10 \mu \mathrm{g}$ RNA was used for the first strand cDNA synthesis (cDNA synthesis kit; Amersham, Bucks, UK) and $1 / 10$ th or this reaction mixture was used for PCR amplification. The two PCR

Correspondence address; A. Steinkasserer, MRC Immunochemistry Unit, Depl. Biochemistry, South Parks Road, OxFord, OXI 3QU, UK. Fax: (44) (865) 275729 primer sets described by Haskill el al. [7] were used in order to distinguish between RNA trunscripts for he secreted and the intracellular forms of IL.l ra. PCR products were analysed after 30 cycles $\left(94^{\circ} \mathrm{C}\right.$, $\left.1 \mathrm{~min} ; 60^{\circ} \mathrm{C}, 30 \mathrm{~s}, 72^{\circ} \mathrm{C}, 2 \mathrm{~min}\right)$ on a $0.7 \%(w / v)$ agarose gel.

\subsection{Northern biot analysis}

A $10 \mu \mathrm{g}$ portion of lotal RNA was electrophoresed in $1.2 \%(\mathrm{w} / \mathrm{v})$ agarose gel and the RNA transferred to a Hybond-N membrane (Amersham) and hybridised at $65^{\circ} \mathrm{C}$ with a radiolabelled IL-Ira probe derived from HepG2 mRNA by PCR. The blots were washed at high stringency [8].

\subsection{Isolation of IL-Ira clones and cDNA sequencing}

A human liver cDivA library constructed in the eukaryotic expression veetor CDM8 [9] was screened with an IL-1 ra probe derived from HepG 2 mRNA by PCR. The length of the positive cDNA clones was estim: ..d by a Pstl-Find III restriction digest. The sequence was determined from both strands using the double-strand sequencing $k$ it from Pharmacia (Milton Keynes, UK),

\section{RESULTS AND DISCUSSION}

Using specific PCR primers it was possible to amplify an IL-1 ra transcript from the hepatoma cell line HepG2 and from total liver RNA. In liver only the secreted form of the antagonist was present (Table I) and no amplification product was obtained for the intracellular form. Interestingly no amplification product was obtained from the Chang liver cell line which is derived from nonmalignant human liver tissue, indicating a loss of the IL-1ra message in this cell line or need for an external stimulus. As a positive control the monocytic cell line U937 was used. The other cell lines (Molt4, HL60, Daudi, T47D and Raji) and tissues (temporal cortex and lung) were negative for the secreted ('iable I) as well as for the intracellular IL-1ra (data not shown).

To confirm the PCR analysis, Northern blots were periormed with RNA extracies from liver lissue and from the cell lines HepG2, Chang and Raji. As shown 


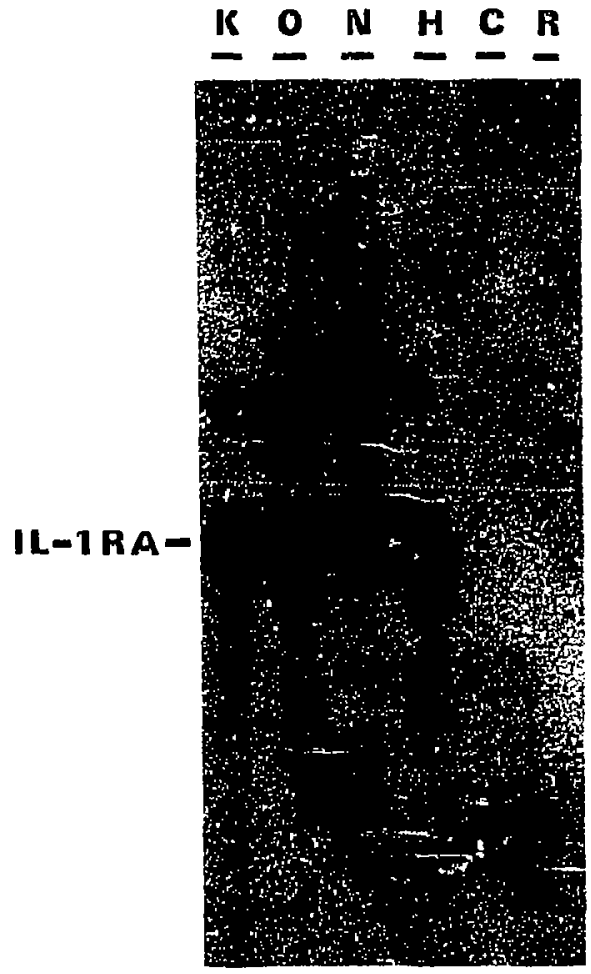

Fig. 1. Northern blot analysis of total RNA isolated from liver tissue (lanes 1-3; individuals: $K, O, N$, and the cell lines HepG2 (H), Chang (C) and Raji (R) probed with an IL-1 ra cDNA probe. The additional fainter bands are probably due to background-hybridization or not totally spliced mRNA.

in Fig. 1 all three liver RNAs (individuals: $K, O, N$ ) contained the IL-1 ra transcript (lanes 1-3), as did the HepG2 cell line (lane 4). No IL-I ra transcript was detected in the cell lines Chang and Raji (lanes 5 and 6 ), in agreement with the findings obtained by PCR analysis.

To establish the sequence of this liver IL-1 ra transcript a liver cDNA library subcloned into the CDM8 expression vector was screened with an IL-I ra probe. Three positive clones were isolated and a $1.65 \mathrm{~kb}$ insert from clone pIL1ra-L was sequenced. This clone contains a short 5 -untranslated region $(8 \mathrm{bp})$ followed by

Table I

PCR analysis of cell line and tissue eDNA transcripts

\begin{tabular}{lll} 
& & sec. IL-I ra \\
\hline HepG2 & (hepatoma) & + \\
Chang & (hepatocyte) & - \\
Liver & (tissue) & + \\
U937 & (monocytic) & + \\
Ditudi & (B-lymphoblastoid) & - \\
HL60 & (neutrphilic) & - \\
Molt4 & (T-lymphoblastoid) & - \\
Ruji & (B-lymphoblatioid) & - \\
T47D & (breast carcinoma) & - \\
Cortex & (tissue) & - \\
Lung & (tissue) & - \\
\hline
\end{tabular}

the leader sequence and the coding region for the mature secreted protein. The 3'-untranslated region is 1108 bp long. Sequence comparison revealed that this sequence is identical to the cDNA corresponding to the secreted form of the IL-1ra from monocytes [3].

Since the IL-ra transeript was detected (by PCR and Northern blot) in liver tissue as well as in the hepatoma cell line HepG2 the transeript in the tissue is likely to be derived from hepatocytes and therefore represents a true IL-1 ra transeript in human liver.

Zahedi et al. demonstrated the induction of the ILI ra gene during inflammatory and acute phase reactions in the mouse liver, suggesting a possible involvement in the control of inflammatory mediators [10]. Many proteins involved in immune and inflammatory responses are expressed and/or controlled in the liver by an IL-1 stimulus mainly derived from macrophages. This includes several complement proteins such as C3, $\mathrm{C} 5$ and Factor $\mathrm{B}$ as well as acute phase proteins such as serum amyloid $P$ component $[11]$ and serum amyloid A [12]. It is necessary to controi this IL-1 transcriptional activation in the liver in order to prevent an overexpression which could lead to pathophysiological effects. Therefore, the existence of a natural IL-1 ra expressed in the liver is essential and the knowledge of the cDNA sequence of this tianscript opens the possibility to investigate the specific control and the interaction with other proteins in the liver environment. The expression of the secreted form of the IL-1 ra in liver is consistent with the fact that this protein competes in the extracellular environment with IL-1 for the binding to IL-1 receptors.

Acknowledgenents: We would like to thank Dr K.B.M. Reid for helpful discussion and critisism of the manuseript. This work is a contribution from the Oxford Centre of Molecular Science (OCMS) which is supported by SERC and the MRC. A.S. was supported by an OCMS post-doctoral lellowship. We also thank the Yamanouchi Research Instilute UK for support.

\section{REFERENCES}

[1] Arend, W.P., Joslin, F.G. and Massoni, R.J. (1985) J. Immunol. $134,3868-3875$.

[2] Dinarello, C.A. and Thompson, R.C. (1991) 1mmunol. Today 12 , $404-410$.

[3] Eisenberg, S.P., Evans, R.J., Arend, W.P., Verderber, E., Brewer, M.T., Hannum, C.H. and Thompson, R.C. (1990) Nature 343, $341-346$.

[4] Steinkasserer, A., Koelble, K. and Sim, R.B. (1991) Nucleic Acids Res. 19, 5095.

[5] Steinkasserer, A., Spurr, N.K., Cox, S., Jeggo, P. and Sim, R.B. (1992) Genomies 13, 654-657.

[0] Lennard, A., Gorman, P., Carrier, M., Scotney, H., Sheer, D. and Solari, R. (1992) Cytokine 4, 83-89.

[7] Haskill, S., Martin, G., Yan Le, L., Morris, J., Peace, A., Bigler. C.F., Jafte, G.J., Hammerberg, C., Sporn, S.A., Fong, S., A rend, W.P. and Ralph, P. (1991) Proc. Natl. Acad. Sci. USA 88, 36813685.

[8] Maniatis, T.. Fritsch, E.F. and Sambrook, J. (1982) A Laboratory Manual, Cold Spring Harbor Press, Cold Spring Harbor. 
[9] Estaller, C., Schwaeble, W., Dierich, M.P. and Weiss, E.H. (1991) Eur. J. Immunol. 21, 799-802.

[10] Zahedi, K., Seldin, M.F., Rits, M., Ezekowitz, A.B. and Whitehead, A.S. (199l) J. Immunit. 146, 4228-4233.
[11] Zahdi, K. and Whitehead, A.S. (1989) J. Immunol. 143, 28802886.

[12] Steinkasserer, A., Weiss, E.H., Schwacble, W. and Linke, R.P. (1990) Biochem. J. 268, 187-193. 